2 Anaerobic Oxidation of Methane Coupled with Dissimilatory Nitrate Reduction

3 to Ammonium Fuels Anaerobic Ammonium Oxidation

4 Wen-Bo Nie ${ }^{\#, 1}$, Jie Ding ${ }^{\#, 1}$, Guo-Jun Xie*,1, Lu Yang ${ }^{2}$, Lai Peng ${ }^{3}$, Xin Tan ${ }^{1}$, Bing-

$5 \quad$ Feng Liu ${ }^{1}$, De-Feng Xing ${ }^{1}$, Zhiguo Yuan ${ }^{4}$ and Nan-Qi Ren ${ }^{1}$

6 Affiliations and footnote:

$7 \quad$ \#These authors contributed equally to this work.

8 *Corresponding author. Mailing address: School of Environment, State Key

9 Laboratory of Urban Water Resource and Environment, Harbin Institute of

10 Technology, No.73, Huanghe Road, Nan'gang District, Harbin City, Heilongjiang

11 Province, China;

12 E-mail: xgj@hit.edu.cn (G.J.X);

13 Tel/Fax: +86 45186282008.

$14{ }^{1}$ School of Environment, State Key Laboratory of Urban Water Resource and

15 Environment, Harbin Institute of Technology, Harbin 150090, China

16 2Singapore Centre for Environmental Life Sciences Engineering (SCELSE), Nanyang

17 Technological University, Singapore 637551, Singapore

$18{ }^{3}$ School of Resources and Environmental Engineering, Wuhan University of

19 Technology, 122 Luoshi Road, Wuhan 430070, China

$20{ }^{4}$ Advanced Water Management Centre, The University of Queensland, St Lucia,

21 Brisbane QLD 4072, Australia

22 Conflict of Interest: The authors declare no financial, commercial, or personal

23 conflict of interest involving the publication of this work.

\title{
Document prepared:
}




\section{Synthetic mineral medium}

Synthetic mineral medium was used for the growth of microorganisms. The composition of the medium was as following (per liter): $\mathrm{KH}_{2} \mathrm{PO}_{4}, 0.075 \mathrm{~g}$;

$\mathrm{CaCl}_{2} \cdot 2 \mathrm{H}_{2} \mathrm{O}, 0.300 \mathrm{~g} ; \mathrm{MgSO}_{4} \cdot 7 \mathrm{H}_{2} \mathrm{O}, 0.200 \mathrm{~g}$; an alkaline trace element solution, 0.2 $\mathrm{mL}$; and an acidic trace element solution, $0.5 \mathrm{~mL}$. The alkaline $(10 \mathrm{mM} \mathrm{NaOH})$ trace element solution contained (per liter): $\mathrm{SeO}_{2}, 0.067 \mathrm{~g} ; \mathrm{Na}_{2} \mathrm{WO}_{4} \cdot 2 \mathrm{H}_{2} \mathrm{O}, 0.050 \mathrm{~g}$; and $\mathrm{Na}_{2} \mathrm{MoO}_{4}, 0.242 \mathrm{~g}$. The acidic $(100 \mathrm{mM} \mathrm{HCl})$ trace element solution contained (per liter): $\mathrm{FeSO}_{4} \cdot 7 \mathrm{H}_{2} \mathrm{O}, 5.560 \mathrm{~g} ; \mathrm{ZnSO}_{4} \cdot 7 \mathrm{H}_{2} \mathrm{O}, 0.068 \mathrm{~g} ; \mathrm{CoCl}_{2} \cdot 6 \mathrm{H}_{2} \mathrm{O}, 0.120 \mathrm{~g}$; $\mathrm{MnCl}_{2} \cdot 4 \mathrm{H}_{2} \mathrm{O}, 0.500 \mathrm{~g} ; \mathrm{CuSO}_{4}, 1.600 \mathrm{~g} ; \mathrm{NiCl}_{2} \cdot 6 \mathrm{H}_{2} \mathrm{O}, 0.095 \mathrm{~g}$; and $\mathrm{H}_{3} \mathrm{BO}_{3}, 0.014 \mathrm{~g}$ 1, 2 .

\section{Detailed methods for ${ }^{15} \mathrm{~N}$ determination}

$\mathrm{NH}_{4}{ }^{+}, \mathrm{NO}_{3}{ }^{-}$, and $\mathrm{NO}_{2}{ }^{-}$in the water samples were transformed to $\mathrm{N}_{2} \mathrm{O}$ by the chemical methods ${ }^{3,4}$. Stable $\mathrm{N}$ isotope of the produced $\mathrm{N}_{2} \mathrm{O}$ is analysed by an analyser-automated PT-IRMS (IsoPrime100, IsoPrime limited, UK) ${ }^{4}$.

Conversion of $\mathrm{NO}_{2}^{-}$to $\mathrm{N}_{2} \mathrm{O}^{4}$. The $\mathrm{NH}_{2} \mathrm{OH} \cdot \mathrm{HCl}$ is used for $\mathrm{N}$ isotope analysis of $\mathrm{NO}_{2}{ }^{-}$. The hydroxylamine hydrochloride reagent, which is much less non-volatile and toxic, is used as an alternative reductant for conversion of $\mathrm{NO}_{2}^{-}$to $\mathrm{N}_{2} \mathrm{O}$. The hydroxylamine hydrochloride reagent stock solutions were prepared with $0.2778 \mathrm{~g}$ of $\mathrm{NH}_{2} \mathrm{OH} \cdot \mathrm{HCl}$ dissolved in $100 \mathrm{~mL}$ of DI water. The working solutions of $\mathrm{NH}_{2} \mathrm{OH} \cdot \mathrm{HCl}$ are prepared fresh by adding $3 \mathrm{~mL}$ of stock solution to $500 \mathrm{~mL}$ DI water. The protocols for the sample preparation before $\mathrm{N}_{2} \mathrm{O}$ isotope analysis are as followed: (1) diluted the samples to $0.5 \sim 20 \mu \mathrm{M} \mathrm{NO}_{2}{ }^{-}$and pipet $4.0 \mathrm{~mL}$ of the pre-processed samples into $20 \mathrm{~mL}$ reaction vials; (2) add $6 \mathrm{M} \mathrm{HCl}$ solution into the vials to lower solution pH below 1 and then crimp seal the vials; (3) inject $4.0 \mathrm{~mL}$ of the hydroxylamine 
hydrochloride working solution by a gastight syringe; (4) keep the vials on a shaker of 120 cycles $\mathrm{min}^{-1}$ with $37^{\circ} \mathrm{C}$ for $10 \mathrm{~h}$; (5) inject $0.5 \mathrm{~mL}$ of $5 \mathrm{M} \mathrm{NaOH}$ solution with the gastight syringe to stop reaction and to absorb $\mathrm{CO}_{2}$ within the vials.

$$
\text { Conversion of } \mathrm{NO}_{3}{ }^{-} \text {to } \mathrm{N}_{2} \mathrm{O}^{3,4} \text {. (1) diluted the samples to } 0.5 \sim 20 \mu \mathrm{M} \mathrm{NO}_{3}{ }^{-} \text {and }
$$
adjust the $\mathrm{pH}$ of the samples to be neutral; (2) pipet $70.0 \mathrm{~mL}$ of the pre-processed samples into $150 \mathrm{~mL}$ reaction vials; (3) add $3 \mathrm{~g}$ (dry weight) activated cadmium power into the samples containing $70 \mathrm{~mL}$ of about $0.5 \sim 20 \mu \mathrm{M} \mathrm{NO}_{3}{ }^{-}$for reducing $\mathrm{NO}_{3}{ }^{-}$ to $\mathrm{NO}_{2}^{-}$; (4) pipet $4.0 \mathrm{~mL}$ of the aforesaid samples into $20 \mathrm{~mL}$ reaction vials; (5) add 6 $\mathrm{M} \mathrm{HCl}$ solution into vials to lower solution $\mathrm{pH}$ below 1 and then crimp seal the vials; (6) inject $4.0 \mathrm{~mL}$ of the hydroxylamine hydrochloride working solution by a gastight syringe; (7) keep the vials on a shaker of 120 cycles $\min ^{-1}$ with $37^{\circ} \mathrm{C}$ for $10 \mathrm{~h}$; (8) inject $0.5 \mathrm{~mL}$ of $5 \mathrm{M} \mathrm{NaOH}$ solution with the gastight syringe to stop reaction and to absorb $\mathrm{CO}_{2}$ within the vials.

\section{Conversion of $\mathrm{NH}_{4}^{+}$to $\mathrm{N}_{2} \mathrm{O}^{4}$. (1) diluted the samples to $10 \sim 20 \mu \mathrm{M} \mathrm{NH}_{4}{ }^{+}$and} pipet the $4.0 \mathrm{~mL}$ of the pre-processed samples into $50 \mathrm{~mL}$ reaction vials and; (2) add $10.0 \mathrm{~mL}$ of $\mathrm{BrO}^{-}$working solution described by the previous study ${ }^{4}$ and then shake vigorously; (3) after $30 \mathrm{~min}$, add $0.05 \mathrm{~mL}$ of $\mathrm{NaAsO}_{2}$ for removing excess $\mathrm{BrO}^{-}$and terminating oxidation; (4) add $6 \mathrm{M} \mathrm{HCl}$ solution into vials to lower solution $\mathrm{pH}$ below 1 and then crimp seal the vials; (5) inject $14.0 \mathrm{~mL}$ of the hydroxylamine hydrochloride working solution by a gastight syringe; (6) keep the vials on a shaker of 120 cycles $\min ^{-1}$ with $37^{\circ} \mathrm{C}$ for $10 \mathrm{~h}$; (7) inject $0.5 \mathrm{~mL}$ of $5 \mathrm{M} \mathrm{NaOH}$ solution with the gastight syringe to stop reaction and to absorb $\mathrm{CO}_{2}$ within the vials. 


\section{Determination the activity of key functional microorganisms in MBfR}

During day 546 549 of MBfR operation, Batch test A, B, C and D were conducted to investigate the nitrogen conversion activity of n-DAMO archaea, nDAMO bacteria, heterotrophic denitrification and Anammox, respectively. Before the Batch test $\mathrm{A}$ and $\mathrm{B}$, methane supplying from the hollow fiber membranes was terminated and the MBfR was flushed a gas mixture (v/v, 95\% $\mathrm{CH}_{4} / 5 \% \mathrm{CO}_{2}$ ) with a flow rate of $50 \mathrm{~mL} \mathrm{~min}^{-1}$ for $30 \mathrm{~min}$, giving a rise to an initial dissolved methane concentration about $19 \mathrm{mg} \mathrm{CH}_{4} \mathrm{~L}^{-1}$. After that, concentrated nitrate (Batch Test A) or nitrite (Batch Test B) solutions was injected to MBfR system to maintain the initial nitrate and nitrite concentration of about $100 \mathrm{mg} \mathrm{NO}_{3}^{-}-\mathrm{N} \mathrm{L}^{-1}$ and $25 \mathrm{mg} \mathrm{NO}_{2}^{-}-\mathrm{N} \mathrm{L}^{-1}$, respectively. In Batch Test $\mathrm{C}$, the dissolved methane in MBfR was stripped out by flushing a gas mixture $\left(\mathrm{v} / \mathrm{v}, 95 \% \mathrm{Ar} / 5 \% \mathrm{CO}_{2}\right)$ with a flow rate of $50 \mathrm{~mL} \mathrm{~min}{ }^{-1}$ for 30 min. The initial nitrate and nitrite concentration were about $100 \mathrm{mg} \mathrm{NO}_{3}{ }^{-}-\mathrm{N} \mathrm{L}^{-1}$ and 25 $\mathrm{mg} \mathrm{NO}_{2}^{-}-\mathrm{N} \mathrm{L}^{-1}$ to investigate the activity of heterotrophic denitrification. In the batch test $\mathrm{D}$, the dissolved methane was stripped by flushing a gas mixture (v/v, 95\% Ar/5\% $\mathrm{CO}_{2}$ ) into MBfR with a low rate of $50 \mathrm{~mL} \mathrm{~min}-1$ for $30 \mathrm{~min}$. The initial ammonium and nitrite concentration were about $12 \mathrm{mg} \mathrm{NH}_{4}^{+}-\mathrm{N} \mathrm{L}^{-1}$ and $16 \mathrm{mg} \mathrm{NO}_{2}-\mathrm{N} \mathrm{L}^{-1}$ to investigate the activity of Anammox bacteria. Liquid samples of these batch tests were collected from the overflow bottle regularly for analyzing the concentration of $\mathrm{NO}_{3}^{-}, \mathrm{NO}_{2}^{-}, \mathrm{NH}_{4}^{+}$, and dissolved methane.

\section{Inhibition tests of methane-driven $D N R A$ reaction}

To investigate methane-driven DNRA reaction when n-DAMO archaea was inhibited, 
93 a batch test were performed in a $250-\mathrm{mL}$ glass reactor with $115 \mathrm{~mL}$ headspace using

94 the suspended flocs from the parent SBR. At beginning of the batch test, both nitrate

95 and nitrite were supplied to the reactor with the initial concentration of about $50 \mathrm{mg}$

$96 \mathrm{NO}_{3}^{-}-\mathrm{N} \mathrm{L}^{-1}$ and $20 \mathrm{mg} \mathrm{NO}{ }^{-}-\mathrm{N} \mathrm{L}^{-1}$, and the reactor was flushed with the mixed gas of

$9795 \% \mathrm{CH}_{4}$ and $5 \% \mathrm{CO}_{2}$ and then filled into the headspace at about $120 \mathrm{kPa}$. At $5 \mathrm{~h}$ of

98 the test, the mixed gas of $95 \% \mathrm{CH}_{4}$ and 5\% $\mathrm{CO}_{2}$ was replaced with $95 \% \mathrm{Ar}$ and $5 \%$

$99 \mathrm{CO}_{2}$. At the same time, nitrate and nitrite were added into the reactor to make the

100 concentration of nitrate and nitrite in culture medium be $50 \mathrm{mg} \mathrm{NO}_{3}^{-}-\mathrm{N} \mathrm{L}^{-1}$ and $20 \mathrm{mg}$

$101 \mathrm{NO}_{2}^{-}-\mathrm{N} \mathrm{L}^{-1}$, respectively. At $10 \mathrm{~h}$ of the test, the mixed gas of $95 \% \mathrm{Ar}$ and $5 \% \mathrm{CO}_{2}$

102 was replaced with $95 \% \mathrm{CH}_{4}$ and $5 \% \mathrm{CO}_{2}$. At $15 \mathrm{~h}$ of the test, 2-bromoethanesulfonate

103 (BES) was added into the reactor with the finial concentration of about $100 \mathrm{mM}$,

104 which is a specific inhibitor of methyl-coenzyme M reductase inactivating n-DAMO

105 archaea ${ }^{5-7}$. At the same time, nitrate and nitrite were added into the reactor to make

106 the concentration of nitrate and nitrite in culture medium be $50 \mathrm{mg} \mathrm{NO}_{3}^{-}-\mathrm{N} \mathrm{L}^{-1}$ and 20

$107 \mathrm{mg} \mathrm{NO}_{2}^{-}-\mathrm{N} \mathrm{L}^{-1}$, respectively. Liquid samples were collected every $1 \mathrm{~h}$ to measurement

108 of nitrogen species concentrations for monitoring the nitrogen conversion. Sludge

109 samples were also collected every $1 \mathrm{~h}$ to investigate the response of gene expression

110 under different conditions. The tests were conducted in triplicate.

\section{Batch tests for methane-driven DNRA fuel Anammox}

112 To verify that the DNRA process in suspended flocs can fuel Anammox bacteria,

113 the sludge mixture was prepared mixing with Anammox sludge and n-DAMO sludge 
114 at a volume ratio of $1: 4$, giving total biomass concentration of $2.2 \mathrm{~g} \mathrm{VSS} \mathrm{L}^{-1}$. The $\mathrm{n}$ -

115 DAMO sludges from the parent SBR on day 250 described in Figure S3. The

116 Anammox sludges cultured in an SBR for more 500 days and the genus Candidatus

117 Kuenenia accounted for over $85 \%$ of microbial population. The sludge mixture was

118 cultured in the $250-\mathrm{mL}$ glass reactors with $115 \mathrm{~mL}$ headspace. During the batch test,

119 the reactor was flushed with the mixed gas of $95 \% \mathrm{CH}_{4}$ and $5 \% \mathrm{CO}_{2}$, and then filled

120 the mixed gas into the headspace at about $120 \mathrm{kPa}$. In Batch Test $\mathrm{A}$, nitrate was

121 supplied to the reactor with the initial concentration of about $50 \mathrm{mg} \mathrm{NO}_{3}^{-}-\mathrm{N} \mathrm{L}^{-1}$. In

122 Batch Test B, both nitrate and nitrite were supplied to the reactor with the initial

123 concentration of about $50 \mathrm{mg} \mathrm{NO}_{3}^{-}-\mathrm{N} \mathrm{L}^{-1}$ and $20 \mathrm{mg} \mathrm{NO}_{2}^{-}-\mathrm{N} \mathrm{L}^{-1}$. Liquid samples were

124 collected every $1 \sim 2 \mathrm{~h}$ for measurement of nitrogen species concentrations and

125 monitoring the nitrogen conversion. Sludge samples were also collected about every

$126 \quad 1 \sim 3 \mathrm{~h}$ to investigate the response of gene expression under different conditions. The

127 tests were conducted in triplicate. 
128 Table S1 Operation conditions of the MBfR

\begin{tabular}{llll}
\hline Phase & Operation time & HRT $(\mathrm{d})$ & Nitrate loading rate $\left(\mathrm{g} \mathrm{N} \mathrm{L}^{-1} \mathrm{~d}^{-1}\right)$ \\
\hline Start-up phase & Day $0 \sim 88$ & NA & NA \\
Continuous phase & Day $89 \sim 149$ & 18.38 & 54.41 \\
& Day $150 \sim 205$ & 13.23 & 75.59 \\
& Day $206 \sim 250$ & 10.32 & 96.90 \\
& Day $251 \sim 276$ & 7.21 & 138.70 \\
& Day $277 \sim 296$ & 5.23 & 191.20 \\
Day $297 \sim 317$ & 4.17 & 239.81 \\
Day 318 337 & 3.11 & 321.54 \\
Day 338 364 & 2.40 & 416.67 \\
Day 365 382 & 1.95 & 512.82 \\
Day 383 402 & 1.56 & 641.03 \\
Day $403 \sim 433$ & 1.31 & 763.36 \\
Day $434 \sim 466$ & 1.12 & 892.86 \\
Day $467 \sim 559$ & 0.98 & 1020.41 \\
\hline
\end{tabular}


130 Table S2 Oligonucleotide probes used in this study

\begin{tabular}{llll}
\hline Probe & 5'-3' Sequence & Specificity & Ref. \\
\hline S-*-DARCH-0872-a-A-18 & GGCTCCACCCGTTGTAGT & n-DAMO archaea & 2 \\
S-*-NC10-1162-a-A-18 & GCCTTCCTCCAGCTTGACGCTG & n-DAMO bacteria & 8 \\
S-*-Amx-820-a-A-18 & AAAACCCCTCTACTTAGTGCCC & Anammox bacteria & 9 \\
\hline
\end{tabular}


132 Table S3 Primers used in real-time quantitative reverse transcriptase PCR

\begin{tabular}{|c|c|c|c|}
\hline Target & Primers & 5'-3' Sequence & Ref. \\
\hline Total bacteria and archaea $16 \mathrm{~S}$ & $926 \mathrm{~F}$ & AAACTYAAAKGAATTGRCGG & \multirow{2}{*}{10} \\
\hline rRNA gene & $1392 \mathrm{R}$ & ACGGGCGGTGWGTRC & \\
\hline n-DAMO archaea $16 \mathrm{~S}$ rRNA & p2F_DAMO & GGGGAACTGCCAGCGTCAAG & \multirow{2}{*}{1} \\
\hline gene & p2R_DAMO & CTCAGCGACTTCGAGTACAG & \\
\hline n-DAMO bacteria $16 \mathrm{~S}$ rRNA & DP397F & TGGCTGTCCAGCTRTYC & \multirow{2}{*}{11} \\
\hline gene & DP569R & GRACGCCTGACGATTRAG & \\
\hline Anammox bacteria $16 \mathrm{~S}$ rRNA & AMX-808-F & ARCYGTAAACGATGGGCACTAA & \multirow{2}{*}{12} \\
\hline gene & AMX-1040-R & CAGCCATGCAACACCTGTRATA & \\
\hline \multirow{2}{*}{$m c r A$} & McrA159F & AAAGTGCGGAGCAGCAATCACC & \multirow{2}{*}{13} \\
\hline & McrA345R & TCGTCCCATTCCTGCTGCATTGC & \\
\hline \multirow{2}{*}{$n r f A$} & NrfA-F2aw & CARTGYCAYGTBGARTA & \multirow{2}{*}{14} \\
\hline & NrfA-R1 & TWNGGCATRTGRCARTC & \\
\hline \multirow{2}{*}{ pmoA } & $\mathrm{cmo} 182$ & TCACGTTGACGCCGATCC & \multirow{2}{*}{15} \\
\hline & cmo568 & GCACATACCCATCCCCATC & \\
\hline \multirow{2}{*}{$h z s A$} & hzsA1597F & WTYGGKTATCARTATGTAG & \multirow{2}{*}{16} \\
\hline & hzsA1857R & AAABGGYGAATCATARTGGC & \\
\hline
\end{tabular}


134 Table S4 Specific n-DAMO archaea activity and ammonium accumulation rate under

135 different concentrations of nitrite

\begin{tabular}{lll}
\hline $\begin{array}{l}\text { Initial } \mathrm{NO}_{2}-\mathrm{N} \text { concentration } \\
\left(\mathrm{mg} \mathrm{NO}_{2}-\mathrm{N} \mathrm{L}^{-1}\right)\end{array}$ & $\begin{array}{l}\text { Specific n-DAMO archaea } \\
\text { activity }\left(\mathrm{g} \mathrm{N} \mathrm{kg}^{-1} \mathrm{VSS} \mathrm{d}^{-1}\right)\end{array}$ & $\begin{array}{l}\mathrm{NH}_{4}{ }^{+}-\mathrm{N}_{\text {accumulation rate }} \\
\left(\mathrm{mg} \mathrm{NH}_{4}{ }^{+}-\mathrm{N} \mathrm{L}^{-1} \mathrm{~d}^{-1}\right)\end{array}$ \\
\hline 0 & 34.35 & 0.03 \\
5 & 32.69 & 1.70 \\
10 & 28.22 & 2.69 \\
20 & 23.18 & 5.97 \\
30 & 14.98 & 9.26 \\
50 & 1.85 & 0.85 \\
\hline
\end{tabular}




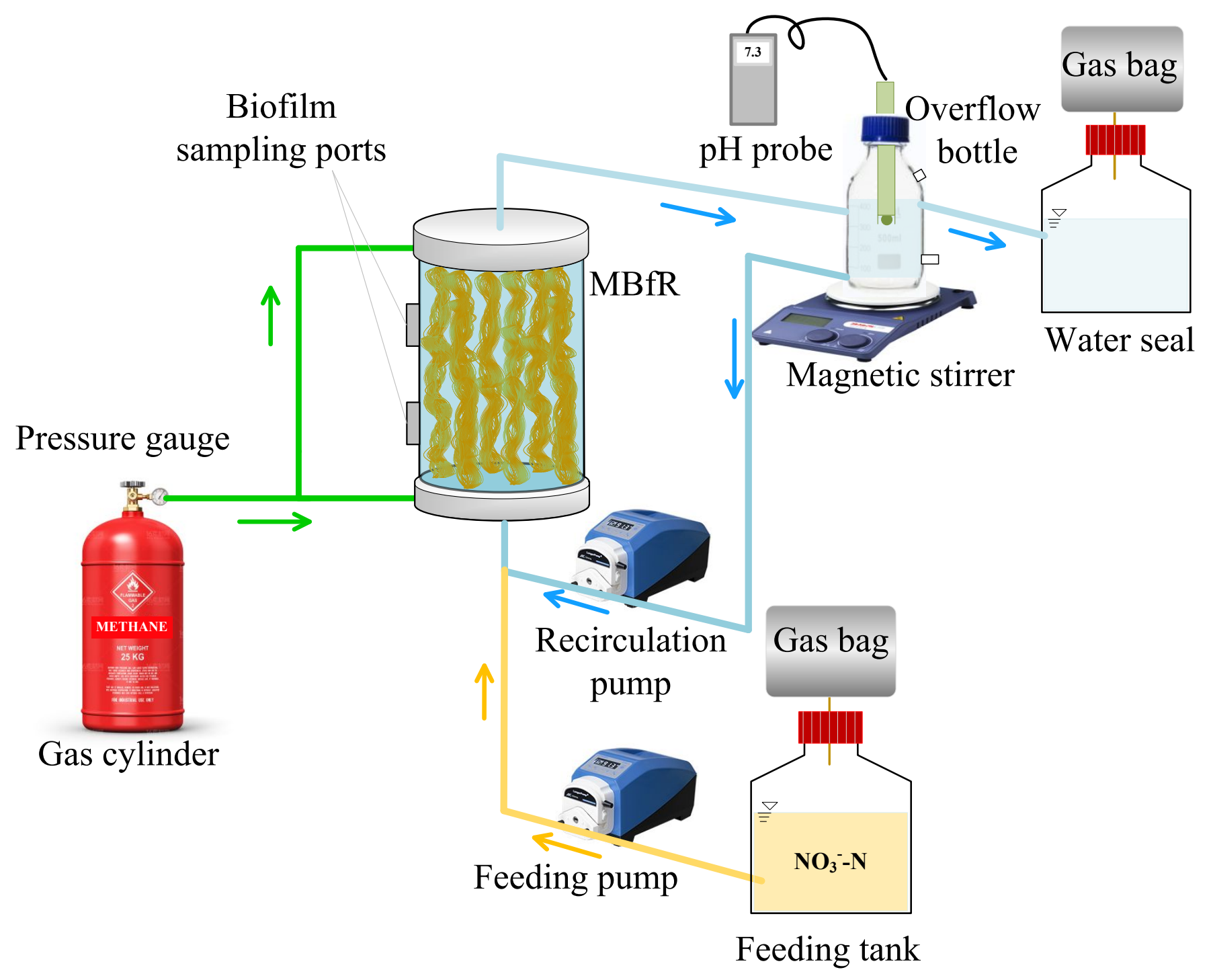

138 Fig. S1 Schematic diagram of MBfR. 

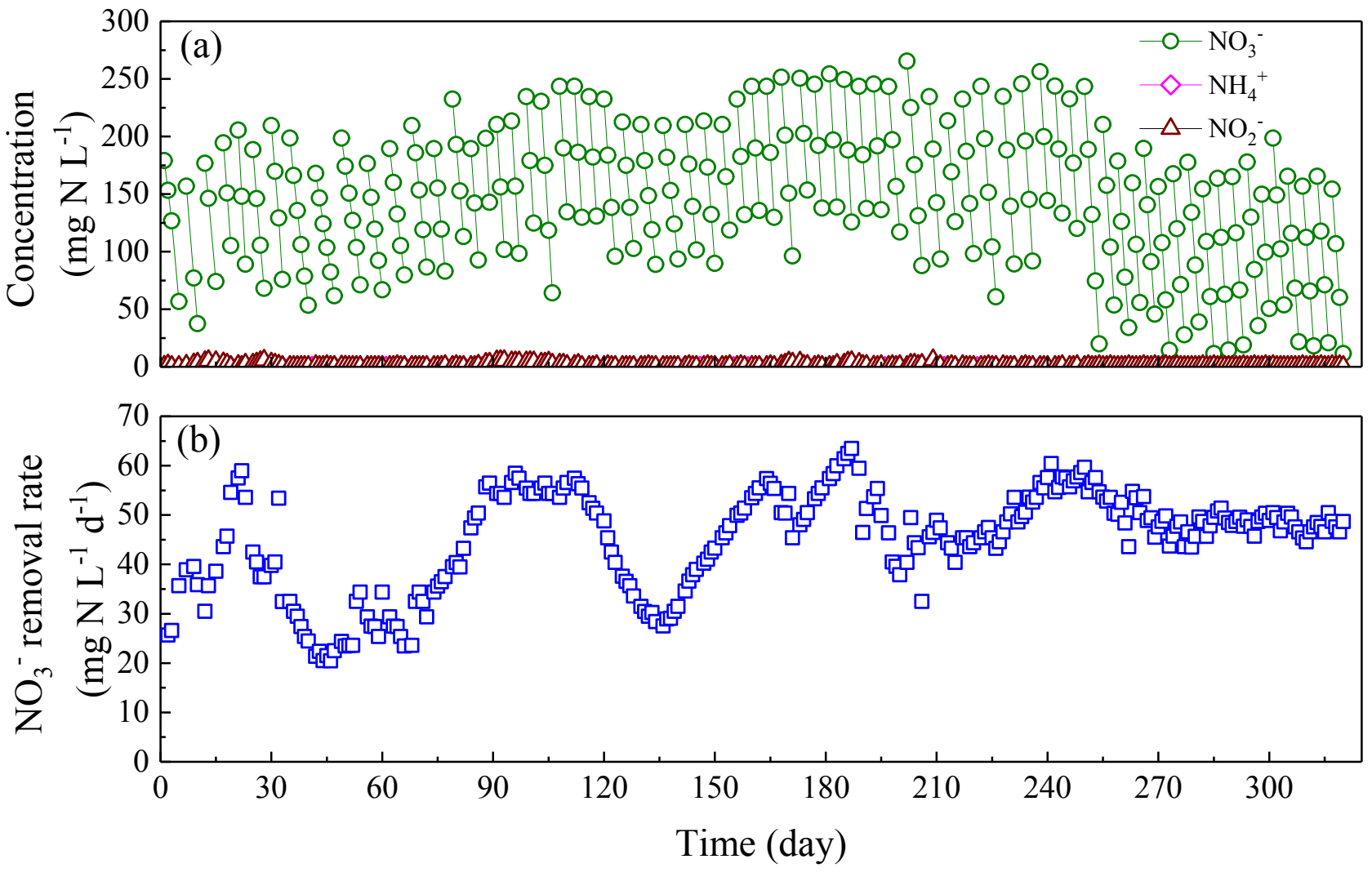

140 Fig. S2 Nitrogen removal performance of the suspended floccular sludge in SBR during 320-day

141 operation, which was inoculated with detached biofilm from MBfR. (a) Variation of $\mathrm{NO}_{3}^{-}, \mathrm{NO}_{2}^{-}$and

$142 \mathrm{NH}_{4}^{+}$concentration and (b) nitrate removal rate. 

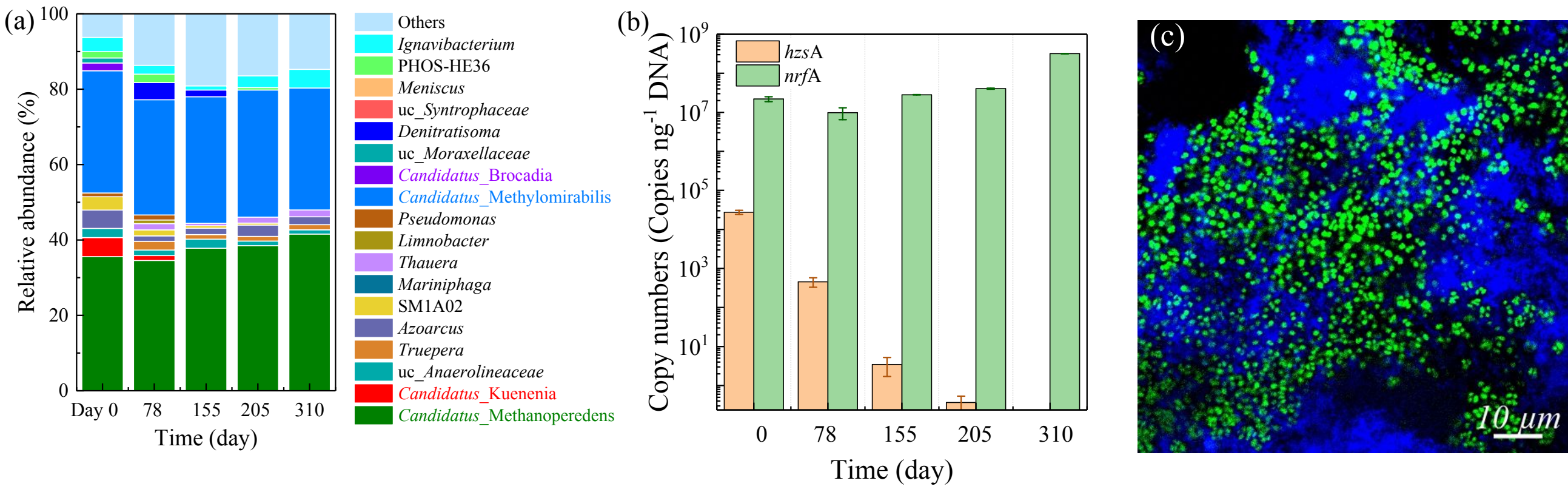

Fig S3 The analysis of microbial community for the suspended floccular sludge in SBR. (a) Relative genus-level abundance of microbial population;

(b) qPCR for quantification of the gene $n r f A$ and $h z s A$ at different SBR operation periods; (c) fluorescence in-situ visualization of sludges on Day 250 of

SBR operation. Relative genus-level abundance of microbial population, taxa with relative abundance of $>0.5 \%$ in the culture were shown, while the remaining taxa were grouped into 'Others'; The prefix uc_ indicates unclassified taxa. n-DAMO archaea appear green hybridization signal form special 

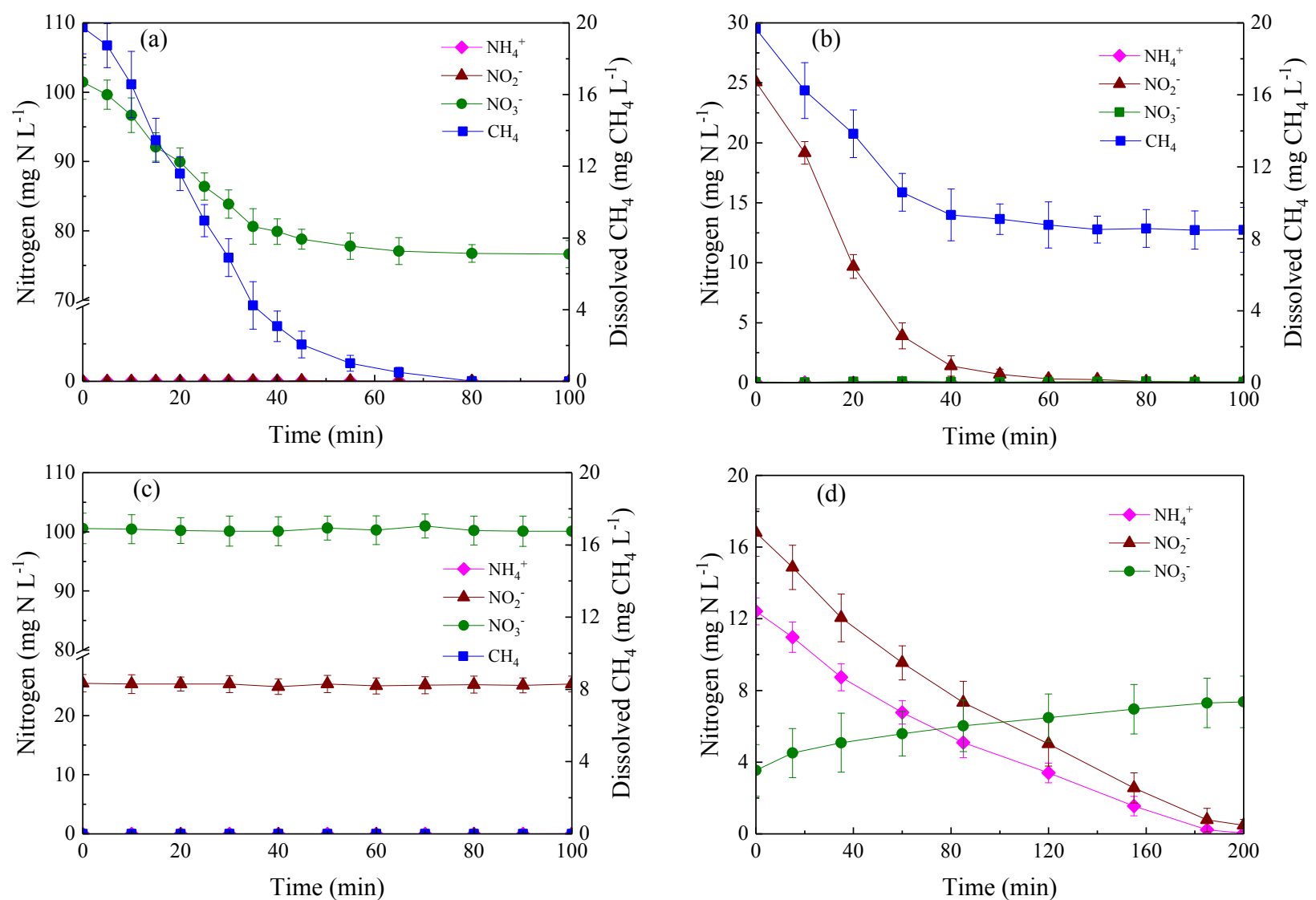

Fig. S4 Nitrogen conversion activity of key functional microorganisms in MBfR. (a) Nitrate

152 removal activity of n-DAMO archaea; (b) nitrite removal activity of n-DAMO bacteria; (c) nitrate

153 and nitrite conversion by heterotrophic denitrification and (d) nitrogen removal activity of

154 Anammox bacteria. 
$\mathrm{NO}_{2}^{-}, \mathrm{NH}_{4}^{+}$concentration $\left(\mathrm{mg} \mathrm{N} \mathrm{L}^{-1}\right)$
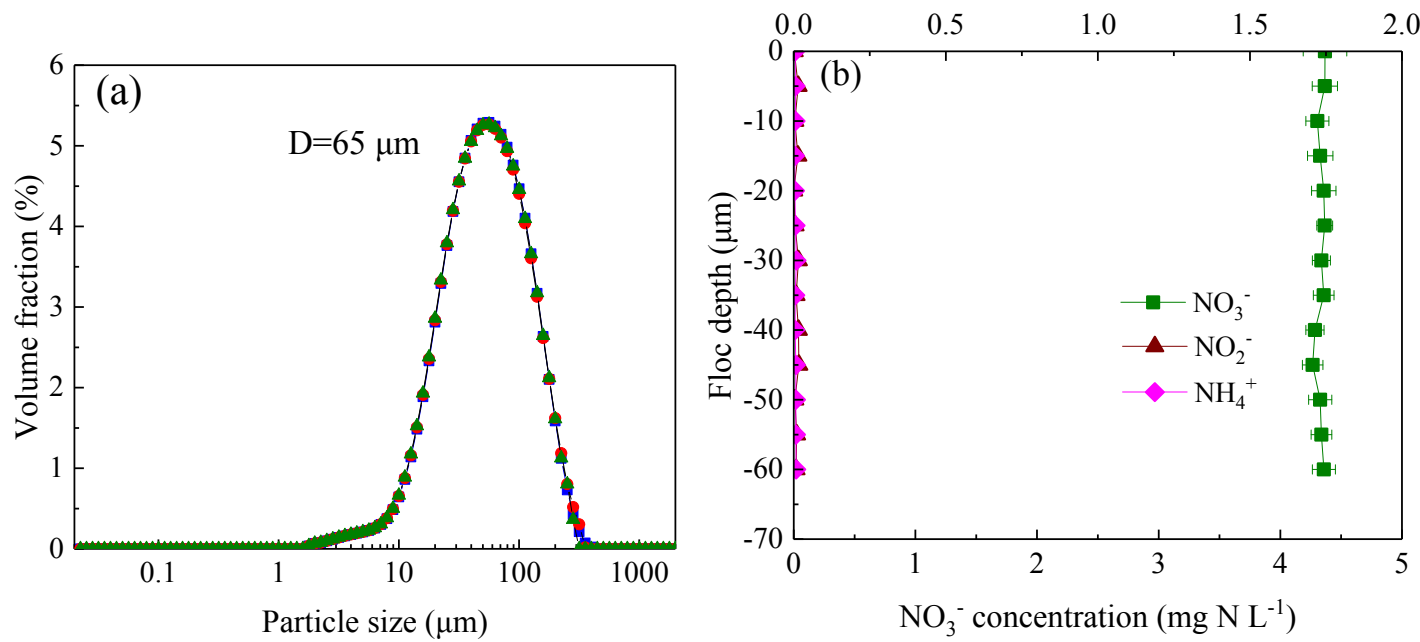

155

Fig. S5 Particle size distribution of flocculent sludge in the SBR measured by laser

157 particle analyzer (a) and $\mathrm{NH}_{4}{ }^{+}, \mathrm{NO}_{2}{ }^{-}$and $\mathrm{NO}_{3}{ }^{-}$concentration profiles inside the

158 flocculent sludge particles (b) on day 285 of SBR operation. 

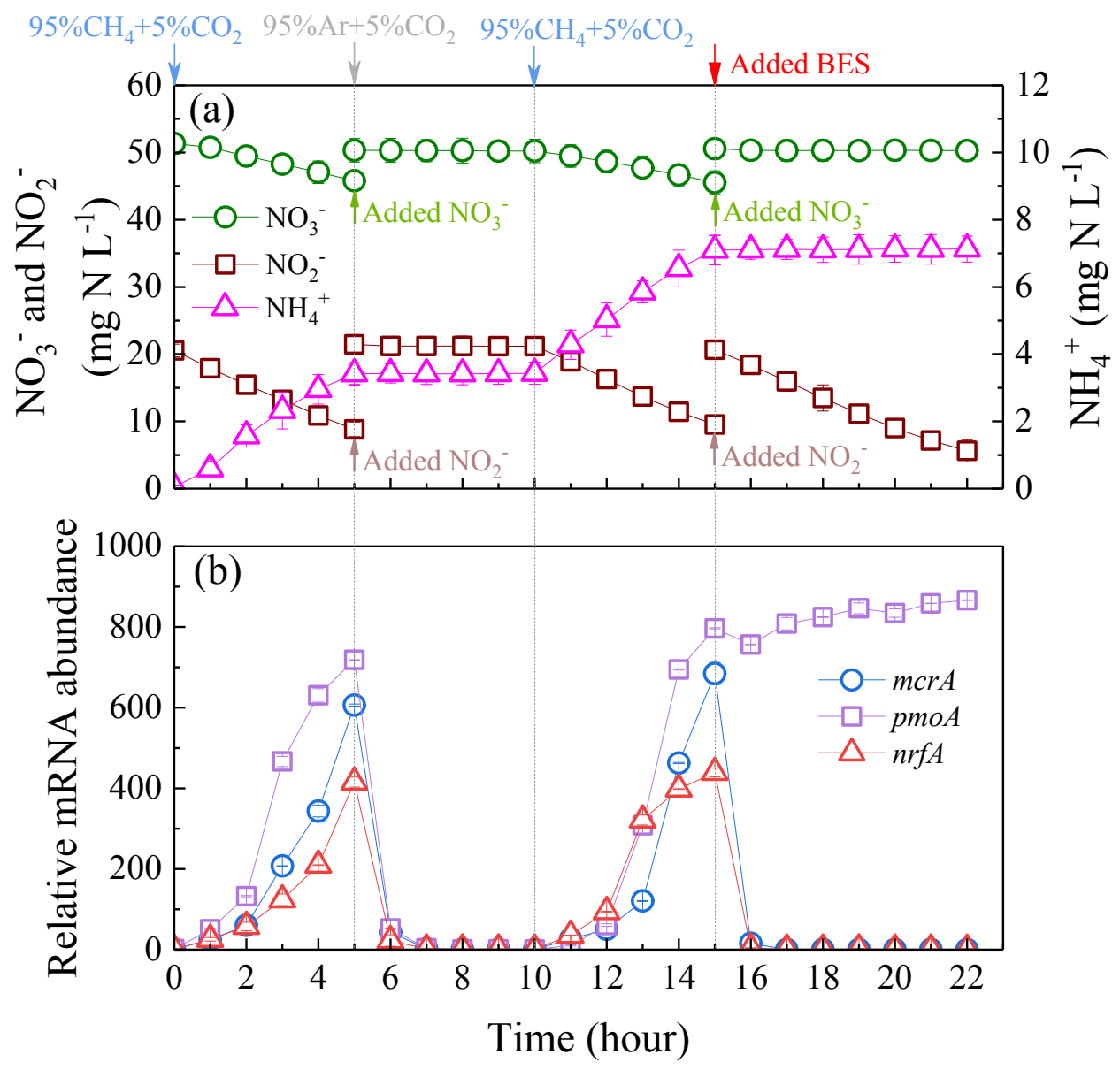

160 Fig. S6 Methane-driven DNRA reaction by n-DAMO archaea in inhibition tests.

161 (a) Nitrogen transformation with initial nitrate and nitrite of about $50 \mathrm{mg} \mathrm{NO}{ }_{3}^{-}-\mathrm{N} \mathrm{L}^{-1}$

162 and $20 \mathrm{mg} \mathrm{NO}_{2}^{-}-\mathrm{N} \mathrm{L}^{-1}$ under different conditions; (b) transcription profiles of

163 functional gene $m c r A, n r f A$ and $p m o A$. Methane in the system was replaced with

164 argon at $5 \mathrm{~h}$ of the batch test, and argon in the system was replaced with methane at

$16510 \mathrm{~h}$ of the batch test. BES was added into the system at $15 \mathrm{~h}$ of the batch test. The $y$

166 axis in (b) shows mRNA abundance normalized to the first sampling time point (i.e.

167 gene $m c r A$ mRNA abundance at $0 \mathrm{~h}$ was 1$)$. 


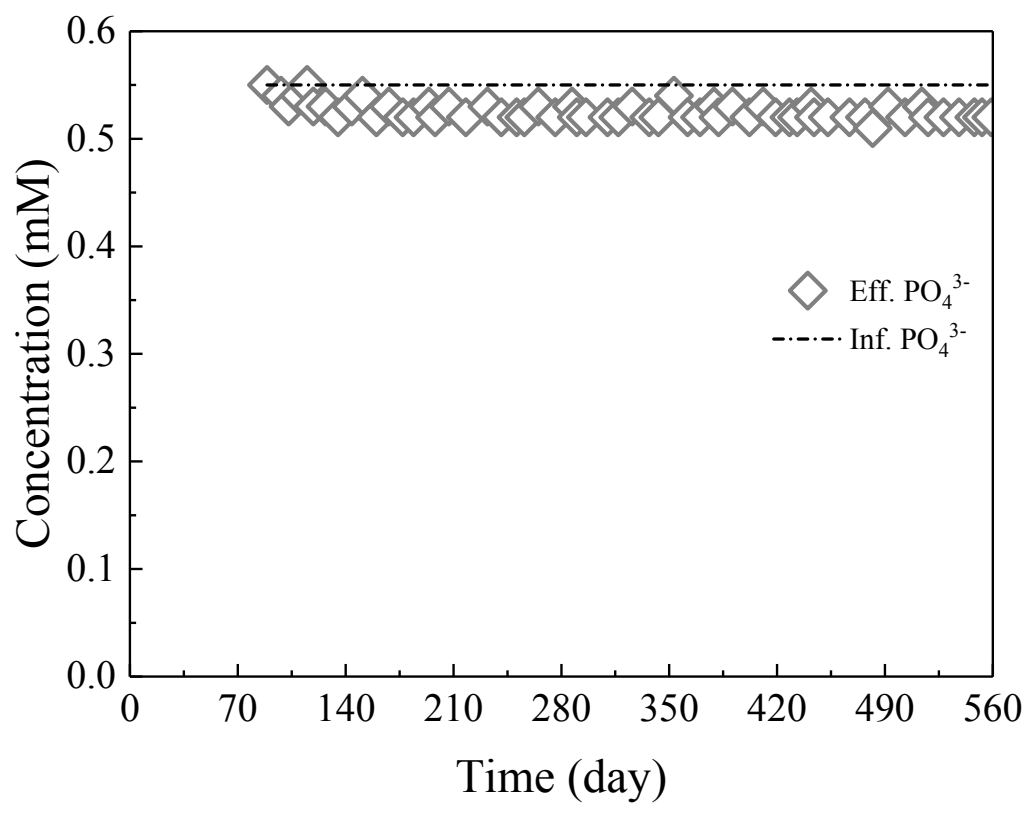

169 Fig. S7 Variation of $\mathrm{PO}_{4}{ }^{3-}$ concentration during 560-day operation of the MBfR. 

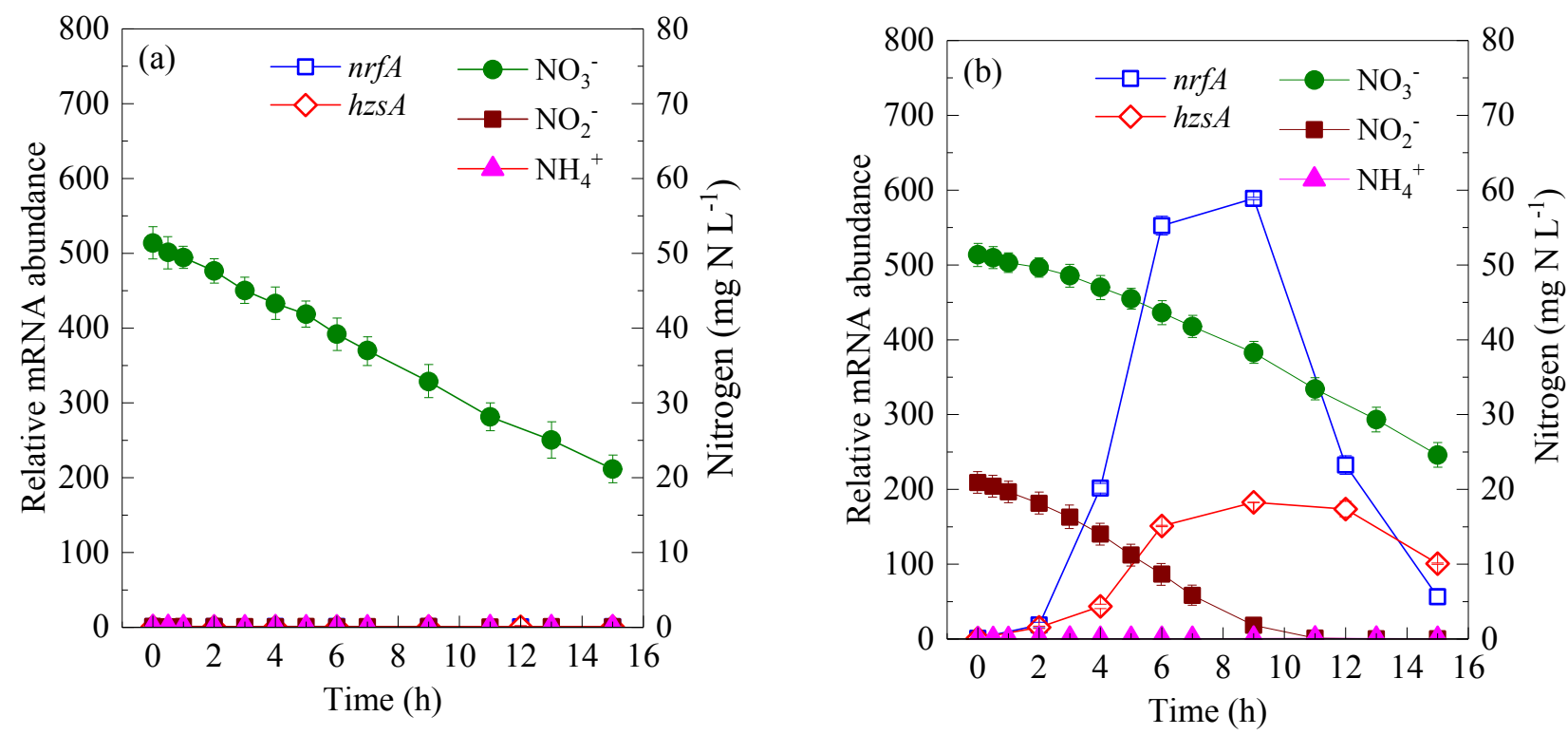

171 Fig. S8 Nitrogen transformation and expression of functional gene $n r f A$ and $h z s A$ in the sludge

172 mixtures of Anammox and n-DAMO microorganisms without nitrite (a) and with nitrite (b).

173 The mRNA abundance normalized to the first sampling time point (i.e. gene $n r f A$ mRNA

174 abundance at 0 hour was 1$)$. 


\section{Reference}

176 1. Ettwig, K. F.; van Alen, T.; van de Pas-Schoonen, K. T.; Jetten, M. S. M.; Strous, 177 M., Enrichment and Molecular Detection of Denitrifying Methanotrophic Bacteria of 178 the NC10 Phylum. Appl. Environ. Microbiol. 2009, 75, (11), 3656-3662.

179 2. Raghoebarsing, A. A.; Pol, A.; van de Pas-Schoonen, K. T.; Smolders, A. J. P.; 180 Ettwig, K. F.; Rijpstra, W. I. C.; Schouten, S.; Damste, J. S. S.; Op den Camp, H. J.

181 M.; Jetten, M. S. M.; Strous, M., A microbial consortium couples anaerobic methane 182 oxidation to denitrification. Nature 2006, 440, (7086), 918-921.

183 3. Ryabenko, E.; Altabet, M. A.; Wallace, D. W. R., Effect of chloride on the 184 chemical conversion of nitrate to nitrous oxide for delta N-15 analysis. Limnology and 185 Oceanography-Methods 2009, 7, 545-552.

186 4. Liu, D.; Fang, Y.; Tu, Y.; Pan, Y., Chemical Method for Nitrogen Isotopic 187 Analysis of Ammonium at Natural Abundance. Anal. Chem. 2014, 86, (8), 3787 1883792.

189 5. Ettwig, K. F.; Shima, S.; van de Pas-Schoonen, K. T.; Kahnt, J.; Medema, M. H.; 190 op den Camp, H. J. M.; Jetten, M. S. M.; Strous, M., Denitrifying bacteria

191 anaerobically oxidize methane in the absence of Archaea. Environ. Microbiol. 2008, 192 10, (11), 3164-3173.

193 6. Park, S.-G.; Rhee, C.; Shin, S. G.; Shin, J.; Mohamed, H. O.; Choi, Y.-J.; Chae,

194 K.-J., Methanogenesis stimulation and inhibition for the production of different target 195 electrobiofuels in microbial electrolysis cells through an on-demand control strategy 196 using the coenzyme $M$ and 2-bromoethanesulfonate. Environ. Int. 2019, 131, 105006.

197 7. Chen, C.; Li, L.; Huang, K.; Zhang, J.; Xie, W.-Y.; Lu, Y.; Dong, X.; Zhao, F.-J., 198 Sulfate-reducing bacteria and methanogens are involved in arsenic methylation and 199 demethylation in paddy soils. The ISME Journal 2019, 13, (10), 2523-2535.

200 8. Hu, S.; Zeng, R. J.; Burow, L. C.; Lant, P.; Keller, J.; Yuan, Z., Enrichment of 201 denitrifying anaerobic methane oxidizing microorganisms. Environ. Microbiol. Rep. 202 2009, 1, (5), 377-384.

203 9. Schmid, M.; Twachtmann, U.; Klein, M.; Strous, M.; Juretschko, S.; Jetten, M.;

204 Metzger, J. W.; Schleifer, K. H.; Wagner, M., Molecular evidence for genus level

205 diversity of bacteria capable of catalyzing anaerobic ammonium oxidation. Syst. Appl.

206 Microbiol. 2000, 23, (1), 93-106.

207 10. Klindworth, A.; Pruesse, E.; Schweer, T.; Peplies, J.; Quast, C.; Horn, M.;

208 Gloeckner, F. O., Evaluation of general 16S ribosomal RNA gene PCR primers for

209 classical and next-generation sequencing-based diversity studies. Nucleic Acids Res.

210 2013, 41, (1).

211 11. Ding, J.; Ding, Z.-W.; Fu, L.; Lu, Y.-Z.; Cheng, S. H.; Zeng, R. J., New primers

212 for detecting and quantifying denitrifying anaerobic methane oxidation archaea in

213 different ecological niches. Appl. Microbiol. Biotechnol. 2015, 99, (22), 9805-9812.

214 12. Hamersley, M. R.; Lavik, G.; Woebken, D.; Rattray, J. E.; Lam, P.; Hopmans, E.

215 C.; Sinninghe Damste, J. S.; Krueger, S.; Graco, M.; Gutierrez, D.; Kuypers, M. M.

216 M., Anaerobic ammonium oxidation in the Peruvian oxygen minimum zone. Limnol.

217 Oceanogr. 2007, 52, (3), 923-933. 
218 13. Vaksmaa, A.; Jetten, M. S. M.; Ettwig, K. F.; Luke, C., McrA primers for the

219 detection and quantification of the anaerobic archaeal methanotroph 'Candidatus

220 Methanoperedens nitroreducens'. Appl. Microbiol. Biotechnol. 2017, 101, (4), 1631-

2211641.

222 14. Welsh, A.; Chee-Sanford, J. C.; Connor, L. M.; Loeffler, F. E.; Sanford, R. A.,

223 Refined NrfA Phylogeny Improves PCR-Based nrfA Gene Detection. Appl. Environ.

224 Microbiol. 2014, 80, (7), 2110-2119.

225 15. Luesken, F. A.; Zhu, B.; van Alen, T. A.; Butler, M. K.; Diaz, M. R.; Song, B.;

226 den Camp, H. J. M. O.; Jetten, M. S. M.; Ettwig, K. F., pmoA Primers for Detection

227 of Anaerobic Methanotrophs. Appl. Environ. Microbiol. 2011, 77, (11), 3877-3880.

228 16. Harhangi, H. R.; Le Roy, M.; van Alen, T.; Hu, B.-1.; Groen, J.; Kartal, B.;

229 Tringe, S. G.; Quan, Z.-X.; Jetten, M. S. M.; Op den Camp, H. J. M., Hydrazine

230 Synthase, a Unique Phylomarker with Which To Study the Presence and Biodiversity

231 of Anammox Bacteria. Appl. Environ. Microbiol. 2012, 78, (3), 752-758. 